Revista Română de Studii Baltice şi Nordice, Vol. 3, Issue 1 (2011): pp. 183-193

\title{
Q YEARS FROM THE ESTABLISHMENT OF DIPLOMATIC RELATIONS BETWEEN FINLAND AND ROMANIA: EXHIBITION OF HISTORICAL DOCUMENTS
}

The National Museum of Romanian History, June 30, 2010

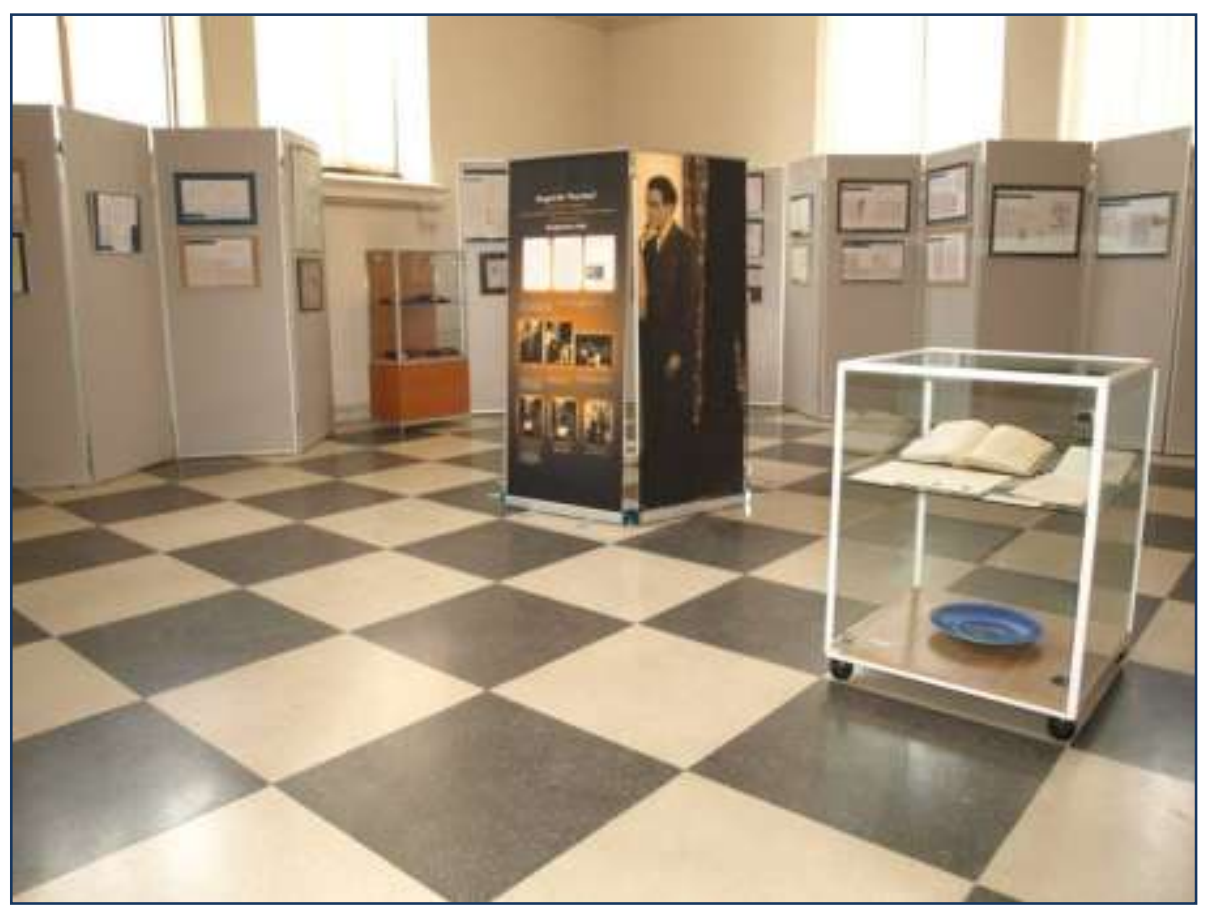




\section{State Secretary at the Ministry of Foreign Affairs Bogdan Mazuru's Address on the Occasion of the $90^{\text {th }}$ Anniversary of the Establishment of Diplomatic Relations between Finland and Romania}

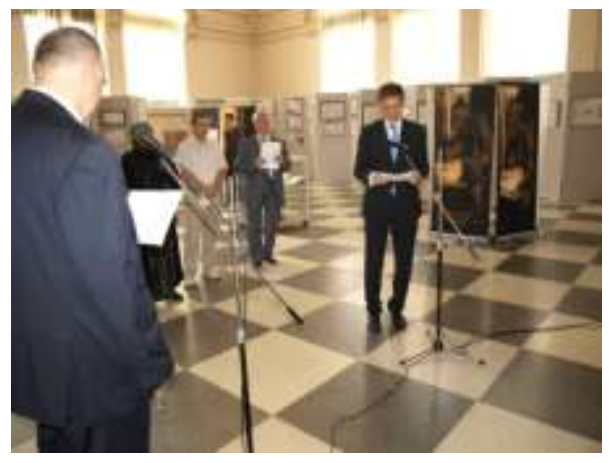

Madame Ambassador, Your
Excellencies, Dear Guests,
It is an honour and a special
pleasure to address, on the occasion of
this anniversary moment of Romania's
diplomatic relations with the Republic
of Finland, the best regards and peace
and prosperity wishes to the Finnish
and Romanian people.
The celebration of 90 years of Romanian-Finnish diplomatic relations gives me the pleasant opportunity to remember the remarkable events that brought the Romanian and Finnish people closer throughout the years.

The début of the diplomatic relations between Romania and Finland is marked by the initiative of the Finnish citizen Edvard Evensen, a merchant from Helsingfors (the old name of the capital Helsinki), who, on 14 June 1890, wrote a letter to the plenipotentiary minister of Romania in Sankt Petersburg, Emil Ghika, proposing the creation of a consular representation of Romania in that city and undertaking the responsibility of managing it. Obviously, the consulate would have been subordinated to the Romanian legation in the capital of the Russian Empire, as Finland was then a Russian guberniya.

On 11 October 1890, the Romanian Minister of Foreign Affairs, Alexandru N. Lahovary, informed St. Petersburg of the favourable endorsement of the Romanian authorities and Mr. Evensen was appointed vice-consul of the Kingdom of Romania and was accepted by the Tzar of Russia, Alexander III (17 June 1891).

It was the first diplomatic representation of Romania in Finland, which on 6 December 1917 proclaimed its independence. The next one was the Legation of Romania, which was established in the years immediately following the First World War.

The Legation of Finland in Bucharest was established in the summer of 1920 and it was led by Väinö Tanner, first in capacity of 
chargé d'affairs, then envoy extraordinaire and plenipotentiary minister, as of 26 June 1921, when he submitted the credentials in this official capacity.

Thus we notice that the end of the First Wold War was to bring fundamental events to the political life of the two states: the unification of Bessarabia, Bucovina and Transylvania with the Kingdom of Romania and the creation of Great Romania (1 December 1918), respectively the proclamation of Finland's independence, recognized by the Soviet Union on 31 December 1917. The young independent state of Finland was proclaimed Republic on 17 July 1919. Romania was one of the first countries that, in the spring of 1920, recognized the independent and sovereign Finnish state.

As a matter of fact, this year we also celebrated the $90^{\text {th }}$ anniversary of the recognition of Finland's independence by Romania. To mark this moment, on 8 April 2010, at Târgovişte, a remarkable exhibition of historic documents was organized and the book "O conceptie românească asupra nordului, sec. XIX-XX" (en. A Romanian View of the North, $1^{\text {th }}$ and 20 $0^{\text {th }}$ Century) having Silviu Miloiu, Oana Lăculiceanu and Elena Dragomir as authors was launched, all this under the patronage of Madame Irmeli Mustonen, Ambassador Extraordinaire and Plenipotentiary of Finland in Bucharest and with the enthusiastic support of the Romanian Association for Baltic and Nordic Studies and National Museal Complex Curtea Domnească of Târgovişte. The event has enjoyed a great deal of attention from the diplomatic body accredited in Romania, from the academic and university medium and also from the local authorities. Such events are meant to reunite the cultural and historic values of our countries and to create perspectives to enrich and diversify the cultural cooperation between Romania and Finland.

\section{Honourable Audience,}

The Romanian-Finnish bilateral relations have been developing at a fast pace. Under political aspect, the relations are excellent, the dialogue at high presidential, parliamentary and governmental level, but also at technical level being carried out according to a busy schedule. On 9 June 2008, Madame President Tarja Halonen visited Romania at the invitation of Traian Băsescu, the President of Romania. The two heads-of-state decided to intensify the dialogue between our countries on the topic of the new EU neighbours, the South-Eastern European space and Black Sea area, as well as on topics of mutual interest on the European agenda.

We may say that between Romania and Finland there is an affinity and a desire to become closer that contributed, throughout the years, to the 
intensification and diversification of the diplomatic, economic and cultural relations.

The economic relations follow an upward trend but the trade has not yet reached the level that we would like. There is a real interest for the intensification and diversification of the contacts between economic operators, professional associations, chambers of commerce, as well as for organization of specialized economic missions in the two countries. It depends on us to efficiently use the commercial potential existing between Romania and Finland, to increase the number of Finnish investments in our country and to encourage the business people in Romania to be more dynamic and to enter the Finnish market. Romania is interested in benefiting from the Finnish expertise in the field of research and intensifying the cooperation in the fields of innovation and technology of the future.

On 31 December 2009 the total volume of Romanian-Finnish trade exchanges has reached the amount of 206 million Euros. Romania and Finland have the potential for strengthening the economic cooperation. It gives me pleasure to underline the presence of Finnish investors on the Romanian market, amongst which the most important is Nokia. The signing on 26 March 2007 in Bucharest, of a Memorandum of Understanding between Cluj County Council and Nokia Company regarding the establishment of an industrial park, respectively the building of a mobile telephone production unit in Jucu Commune led to the achievement of the most important Finnish investment in Romania. We can also singularize other Finnish companies that are investing in Romania, such as Rautaruukki (Ruukki) manufacturer of integrated metal systems, which established its headquarters in Giurgiu, UPM-Kymmene Corporation, OMX Group, Automaster OY, the Finnish Group Consolis manufacturer of prefabs, etc. We appreciate the presence of the Finnish investors on the Romanian market and, at the same time, we encourage Finnish economic operators to also use the free trade areas on the banks of Danube and in Constanta harbour, in order to facilitate the transport of goods.

\section{Madame Ambassador, Your Excellencies, Dear Guests,}

In conclusion, I wish to remind you that Romania found in Finland a reliable friend and partner that supported us in our path towards the European Union and shared the Romanian people's aspirations to accede to the great family of the united Europe. The decision to begin negotiations with Romania was adopted by the European Council in Helsinki in 1999 and that of completing the process was adopted also during the Finnish 
90 years from the establishment of diplomatic relations between Finland and Romania

Presidency of the European Council, in the second half of 2006. Thus, the process of accession of Romania to the EU was carried out "from Helsinki to Helsinki".

\section{Thank you very much}

Happy Anniversary Finland! Happy Anniversary Romania! 


\section{Speech by H.E. Ambassador of Finland Ms. Irmeli Mustonen \\ on the Occasion of the 90 $90^{\text {th }}$ Anniversary of the Establishment of Diplomatic Relations between Finland and Romania}

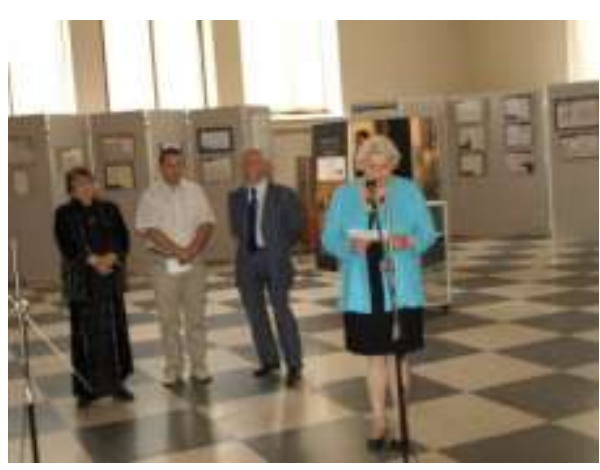

Excellencies, Ladies and Gentlemen,

It gives me great pleasure to welcome you today to celebrate the 90 th Anniversary of the diplomatic relations between Romania and Finland. It is particularly pleasant to see that so many friends of Finland have followed the invitation in spite of the starting holiday season.

Let me start by expressing my gratitude to the representatives of the Ministry of Foreign Affairs of Romania and the National History Museum for organizing and hosting this event at this beautiful and historic venue. I would also like to extend my special thanks to the Romanian Association for Baltic and Nordic Studies, whose representatives have done a great job putting together the exhibition of documents that surround us, - presenting many of the milestones of Romanian-Finnish relations, and thus making history more palpable.

The development of the Romanian-Finnish relations is very well illustrated by these documents. They introduce different areas and levels of contacts between Romanians and Finns. Their source is not only the archives of the Ministries for Foreign Affairs of both countries, but also many other archives, in which the main authors of this Exhibition, Mr. Silviu Miloiu and Ms. Elena Dragomir, have been conducting some remarkable research activity over the years.

\section{Ladies and Gentlemen,}

Although few occasional contacts between Finns and Romanians had existed even in earlier centuries, establishing official bilateral relations between the two countries became possible only after the end of the First World War, bringing about some major geopolitical changes in Europe.

Finland declared its independence on 6 December 1917, and very soon our Government presented official requests for the recognition of its independence to other countries. The Kingdom of Romania, whose 
territory had been significantly enlarged as a result of the war, was among the first to be approached. The Finnish request was confirmed by the Government of Romania on April 8, 1920. The establishment of diplomatic relations followed about three months later, when the first Finnish diplomat to Romania, Mr. Väinö Tanner, was officially accredited as chargé d'affaires in Bucharest on 28 June 1920 - the occasion we are commemorating here today. Through its appointment Romania became one of the first countries hosting a Finnish Embassy.

After a very intensive start 90 years ago, when both nations were striving to consolidate their newly acquired favorable status on the international scene, the bilateral relations between Romania and Finland have seen periods of varying activity, most often related to the international context of the moment. Besides the official political and diplomatic relations, contacts between our nations have been developing early on also, for instance, in the cultural and economic fields, the overall trend in our relations being definitely an ascending one.

The most recent upswing was brought about by the accession of Romania to the European Union three and a half years ago - and I like to recall, after a process that was opened by the European Council in Helsinki in 1999, during the Finnish Presidency of the EU, and finalized during our EU Presidency in 2006. - During the last few years we have also been witnessing a steady increase of Finnish investments in Romania, for example in the fields of information technology and forestry. Whatever area of activity you take into consideration, we see a similar pattern, that is, relations between Romania and Finland, between Romanians and Finns, are becoming closer and more and more active.

\section{Ladies and Gentlemen,}

Since the troubled times when the first steps were taken to establish official relations between Romania and Finland, not only both our countries, but also Europe as a whole, have undeniably come a long way, undergoing dramatic changes to the better. Close to a century ago our two nations were seeking each other's support mostly in order to tackle some common external threats. Today we stand side by side, united in a large European family, together with many other partner countries, all sharing the same fundamental values and working together for a peaceful and prosperous European future.

I hope that this Exhibition today will find your appreciation - and, for its part, will contribute to the further strengthening of the ties between our two countries, following the lines that were laid down nine decades ago. 


\title{
Speech by President of the Romanian Association for Baltic and Nordic Studies \\ Dr. Silviu Miloiu \\ on the Occasion of the $90^{\text {th }}$ Anniversary of the Establishment of Diplomatic Relations between Finland and Romania
}

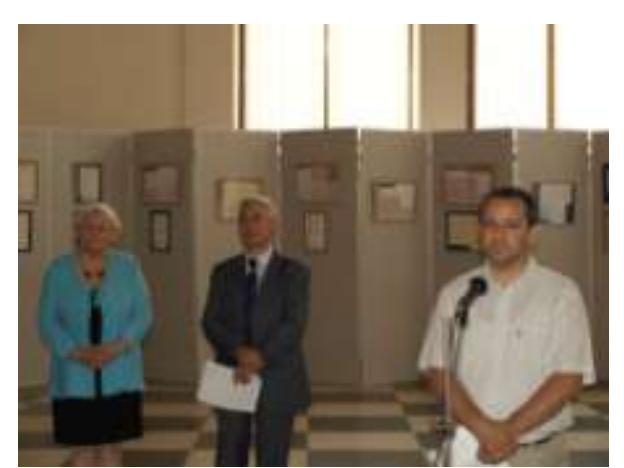

\author{
Your Excellencies, Ladies and \\ Gentlemen,
}

I use this opportunity to thank you on behalf of the Romanian Association for Baltic and Nordic Studies for your participation at the opening of this exhibition destined to celebrate the $90^{\text {th }}$ anniversary of the Romanian-Finnish diplomatic relations. I would also like to express our gratitude to those who have been involved with us in the event organization. Set up in 2008, our association has as a fundamental goal the promotion of research activities and knowledge in the field of Baltic and Nordic Studies and the offering of incentives for initiatives meant to develop the cooperation between the Black Sea and the Baltic Sea regions.

\section{Ladies and gentlemen,}

The opening of this exhibition - which speaks for itself of some of the most important stages and events that have marked the history of the Romanian-Finnish relations - offers us the occasion of a brief review of the ties between the two nations.

As mid-sized nations, for the most part of their history, their contacts with people outside their neighbourhood have been meager. Eventually, a series of domestic and international developments have contributed to the deepening thereof. Thus, the consular relations between the two states have been established on 17 November 1890 in the Russification era taken place both in the Grand Duchy of Finland and in Bessarabia; the Vice-Consulate was upgraded to Consulate on 26 January 1898 and to General Consulate on 20 May 1926. During the interwar period, Finland has also opened an honorary Consulate in Bucharest. 
During World War I, one of the personalities that will play an outstanding role in Finnish history, General Carl Gustaf Emil Mannerheim, struggled on the Romanian front starting with December 1916. Initially at command of the Russian 12 $2^{\text {th }}$ Cavalry Division, Mannerheim's assignment was to defend a frontline situated $40 \mathrm{~km}$ north of Focşani reporting to the commander of the $2^{\text {nd }}$ Romanian Army, General Alexandru Averescu.

Eventually, Mannerheim became in charge of the Vrancea Group consisting of four mixed Russian and Romanian cavalry divisions, two infantry divisions and an infantry brigade. In the battles of December 1916 and January 1917, Mannerheim contributed to the stabilization of the mountain front crossed by rivers Şuşița and Putna. One year later, on 6 December 1917, Finland was proclaimed an independent state, and after another year, Mannerheim became the regent of Finland. The Finnish Government requested the official recognition of its independence from Romania, recognition which was delayed due to the circumstances in which the two countries found themselves at the end of the Great War.

Ultimately, the Finnish endeavours to gain the recognition of its independence arose from the Liberal circles that perceived Soviet Russia and Germany as the two major threats for their country's independence. They envisaged, as proven by the Finnish plans of May and August 1919, the creation of a "diagonal league" to encompass all countries from Finland in the North to Poland and Romania in the South, with the Baltic states, Ukraine, White Russia and Czechoslovakia included. The repeated requests of the Finnish Foreign Minister, Rudolf Holsti, received a favourable answer when his Romanian counterpart, Take Ionescu, the founder of the Little Entente, accepted the idea of getting Finland into a Central European block of states. On 5 April 1920 a telegram of the Romanian Foreign Ministry complied with the Finnish requests of recognizing their independence. The first Finnish diplomat assigned to Bucharest was Väinö Tanner (June 1920), while the first Romanian diplomat accredited to Helsinki was Dimitrie Plesnilă (February 1921).

Starting from Romania, Finland opened its ties and contacts with the states of South-Eastern Europe following Väinö Tanner's visits in the area. Plans for concluding a political alliance and a trade treaty have become an important element on the two states' agenda.

The removal from power of the two artisans of the RomanianFinnish bonds, Holsti and Ionescu, the difficult post-war economic situation and the changes occurring in the Finnish foreign policy resulted into a weakening of the ties between the two countries.

For instance, the economic relations between the two nations have never reached a significant level of goods exchange. In 1920 they only 
reached 62,000 Finnish marks (about 21,713 Euros) and at its peak, in 1934, they have barely exceeded 1 million Euros.

The accreditation of Raoul Bossy as plenipotentiary Minister to Helsinki, on February 1, 1934, has contributed to progresses in the cultural field between the two states. The organization of the two art exhibitions in Helsinki and Bucharest and the publication of two works by Finnish authors with regard to Romania (bearing the signatures of Väinö Tanner and V.J. Mansikka) or by Romanian authors about Finland (the most important one signed by Raoul V. Bossy himself) marked the start of a new stage in the two nations' knowledge of each other. In fact, the Finnish Legation in Bucharest will reopen on 1 June 1939.

Both Romania (its Eastern province of Bessarabia) and Finland were included in the Soviet-German division of spheres of influence in Central Europe - herein understood as the area situated in-between the two Great Powers - of 23 August 1939. The Romanian Foreign Ministry, the General Staff, the Academy and the public opinion carefully witnessed the events prefacing and marking the Winter War, their feelings being divided between the sincere sympathy for the Finnish cause and the relief that the Finnish resistance postponed the predictable outcome of the Soviet pretensions on Romania.

Eventually, willing to reconstitute their territorial and national integrity and influenced by very painful recent traumas, both countries joined in the German aggression against Soviet Union. Even if their domestic policies differed in that period, the recognition by their leadership of the similarities in their international situation and the desire to safeguard their common interests will bring about close relations between the two states. The exchange of political views, a meeting in Berlin between their foreign ministers in the autumn of 1941, the transfer of military and security information, the development of their cultural and commercial ties marked a new climax in the relations between the two nations.

The cultural relations have also reached the peak of their development. As such, a Romanian lectureship was set up in Helsinki, associations for friendship at the highest level were created, a significant number of conferences, concerts, movie screenings, theatrical performances, radio conferences, translations, books publishing, journalists visits occurred. In 1942 the first translation of Kalevala, made by Barbu Brezianu and prefaced by Ion Marin Sadoveanu, appeared in Bucharest. Romanian personalities such as the writer Liviu Rebreanu, the pianist and conductor Sergiu Celibidache, the pianists Silvia Şerbescu and Dinu Lipatti, the dancer Iris Barbura, the violinist Virgil Pop delighted the Finnish audience with their concerts and conferences. 
The same can be said about Finnish visitors of Romania such as the famous conductor Georg Schneevoight, friend of composer Jean Sibelius, Ragmar Numelin or Professor V.J. Mansikka. The premiere of the play Veste Bună (Good News) of Mircea Ştefănescu at the Finnish National Theatre on September 10, 1943, with the daughter of Sibelius, Ruth Snellman, and Urho Somersalmi and Unto Salminen featuring the main characters, marked one of the climaxes of the Romanian spiritual presences in Finland.

The deepening of the mutual knowledge and cultural exchanges is also traceable in the significant number of decorations awarded to Finnish and Romanian personalities who played an important role in the process.

The two countries' withdrawal from war happened approximately in the same period (the months of August and September) and the United Nations' armistice with Finland was modelled by the text of the truce with Romania. However, after the end of the Second World War, Romania entered into the Soviet Union's sphere of influence and became a 'popular democracy', while Finland kept its democratic edifice, but was forced to make compromises in the field of its foreign policy.

\section{Ladies and gentlemen,}

I hope that the exhibition which we can see today will offer you the satisfaction of exploring more closely the history of the relations between the two states and of discovering the interest the two nations have shown to each other in the past two centuries.

Thank you very much for your attention! 